\title{
OBRAZ PROJEKCJĄ DUSZY ARTYSTY NA PODSTAWIE DZIEŁA ADAMA CHMIELOWSKIEGO „OPUSZCZONA PLEBANIA”
}

\section{Streszczenie}

W latach 1870-1874 Adam Chmielowski, późniejszy św. Brat Albert, studiował malarstwo w Monachium. Tam też spotkał grupę polskich artystów, którzy po powstaniu styczniowym i zamknięciu ASP w Warszawie, podobnie jak on, opuścili Polskę. Pod względem artystycznym tworzyli dość jednolitą grupę. Pielęgnowali romantyczną wizję sztuki. Preferowali pejzaż, zamiast tradycyjnego malarstwa historycznego. Tematyką nawiązywali do Polski (powstanie styczniowe, krajobrazy rodzime). Ich obrazy cechowały się specyficznym nastrojem, tajemniczości i kontemplacyjnej ciszy. Obecnie ich twórczość określa się mianem „szkoły monachijskiej”.

Do „szkoły monachijskiej” należy także Chmielowski. Prawdopodobnie już w Monachium ukształtowały się jego poglądy na sztukę, którym pozostał wierny do końca swojej twórczości. Według niego obraz powinien odzwierciedlać duszę artysty. W ten sposób przez obraz artysta może nawiązać kontakt z widzem i odwrotnie.

Tematem artykułu jest próba poznania duszy Chmielowskiego na podstawie jego obrazu Opuszczona plebania. Dzieło ukazuje stan cierpienia duchowego, doświadczenie opuszczenia przez Boga i ludzi. Zestawienie wydarzeń z życia Chmielowskiego z ekspresją obrazu sugeruje, że został on namalowany kilka lat wcześniej (w latach 1882-1884) niż wskazuje data na sygnaturze.

Słowa kluczowe: Adam Chmielowski; brat Albert; „Opuszczona plebania”; malarstwo; ,szkoła monachijska”

$$
* * * * *
$$

W 1994 r. Muzeum Narodowe w Warszawie zakupiło obraz Adama Chmielowskiego Opuszczona plebania ${ }^{1}$, jedno z jego ostatnich notowanych dzieł. Po-

* Renata Wierna - dr teologii, mgr historii sztuki; nauczyciel w Liceum Ogólnokształcącym w Warszawie

e-mail: heyne_wierna@onet.eu

https://orcid.org/0000-0003-4832-1578 
większył on zbiory sali „monachijczyków”, znalazł miejsce blisko innego płótna Chmielowskiego Ogród miłości (1876).

Chmielowski w artykule $O$ istocie sztuki napisał: „(...) w dziele sztuki obchodzi to, co artysta czuł, nie to, co myślał (...)"’2. Na podstawie obrazu Opuszczona plebania zostanie podjęta próba odczytania tego, co Chmielowski „,czuł”, malując wspomniany obraz.

\section{Uzasadnienie tematu}

W latach 1870-1874 Chmielowski przebywał w Monachium celem pogłębienia studiów malarskich. Wyjazd stał się możliwy dzięki stypendium, które ufundował mu hrabia Włodzimierz Dzieduszycki. W Monachium zetknął się ze środowiskiem artystycznym skupionym wokół Akademii Sztuk Pięknych.

Monachijska Królewska Akademia Sztuk Pięknych była ośrodkiem malarstwa realistycznego, z akcentem na tematykę historyczną, a potem i pejzaż, na wzór „szkoły barbizońskiej” i malarstwa Gustava Courbeta. W połowie XIX wieku ukształtował się pejzaż nastrojowy (stimmungowy). Stimmung (niem. nastrój) to specyficzna ekspresja obrazu, która ma sprzyjać jego kontemplacji. Stanowi malarski „,zapis” stanu natury, przez który artysta pragnie wyrazić swój stan duszy.

W Monachium Chmielowski nawiązał kontakt z grupą artystów polskich (Józef Brandt, Maksymilian Gierymski, Aleksander Gierymski, Józef Chełmoński, Stanisław Witkiewicz). Niektórzy z nich wyjechali z kraju po zamknięciu Akademii Sztuk Pięknych w Warszawie (1864). Pod względem artystycznym tworzyli dość jednolitą grupę, którą przyjęło się nazywać ,szkołą monachijską”. Pielęgnowali romantyczną wizję sztuki, więc bliski im stał się pejzaż stimmungowy. Tęsknota za ojczyzną sprawiła, że malowali pejzaż rodzimy z nutą melancholii i smutku. Ta osobliwa nostalgia obrazów stała się wyznacznikiem „monachijczyków”. Pragnęli, aby płótno wyrażało duszę malarza. Chmielowski ujął to w następujący sposób: „dzieła sztuki są duchem i do ducha naszego mówią,”.

Prawdopodobnie już w Monachium skrystalizowały się zasadnicze poglądy Chmielowskiego na sztukę, które wyraził w $1876 \mathrm{r}$. w cytowanym artykule $O$ istocie sztuki. Twórczość artystyczną postrzegał na podobieństwo działania stwórczego Boga. Tak jak każde dzieło stwórcze jest odblaskiem Boga, podobnie obraz jest odblaskiem duszy artysty ${ }^{4}$.

„Obraz i ten, co go robi to jedno, to o tym jestem dowodnie przekonany. Nikt by nie uwierzył, jak to dalece jest prawdą, więc na to rady nie ma". I dalej stwierdza: „Piękno tkwi głównie w malarzu”. Takiej koncepcji sztuki pozostał wierny także w późniejszych latach.

Franciszek Woltyński w pracy Adam Chmielowski (Brat Albert) jako malarz powołując się na relację Leona Wyczółkowskiego, podkreśla, że Chmielowski

${ }^{1}$ Numer inwentarzowy: MP $5221 \mathrm{MNW}$.

${ }^{2}$ A. Chmielowski, O istocie sztuki, „Ateneum Kapłańskie: pismo naukowe i literackie”, 2 (1876) z. 5 , s. 431 .

${ }^{3}$ Tamże, s. 431.

${ }^{4}$ Por. K. Michalski, Brat Albert, Poznań 1978, s. 58.

${ }^{5}$ Tamże, s. 61. 
przywiązywał duże znaczenie do tego, aby obraz współgrał z jego obecnym nastrojem $^{6}$. Takie widzenie sztuki znalazło odpowiedni grunt $\mathrm{w}$ jego melancholijnym temperamencie, skłonnym do marzycielstwa, ale i w jego pobożności.

\section{Prezentacja dziela}

Obraz Opuszczona plebania ma wymiary $71 \times 56,8 \mathrm{~cm}$. Został namalowany techniką olejną na płótnie. Na planie pierwszym jest widoczna droga, po której, w kierunku widza, idzie kobieta z wiązką chrustu na plecach. Jej sylwetka lekko pochylona pod ciężarem chrustu jest otulona wieśniaczym ubraniem, ciemnym pledem i chustą na głowie. Po prawej stronie obrazu widać tytułową plebanię, zogrodem oddzielonym od drogi zmurszałym murem. Obok niej znajduje się niewielki, murowany kościół na planie kwadratu, pokryty dachem czterospadowym z wieżą. Ten sam typ dachu hełmowego można dostrzec w widoku kościoła w Czarnokozińcach (A. Chmielowski, Czarnokozińce nad Zbruczem, 1886). Nad wieżą unosi się stado ptaków. W tle, na końcu drogi jest widoczny fragment białego muru. Pomiędzy nim a budynkiem plebanii na wysokim cokole stoi słabo widoczna rzeźba, prawdopodobnie Maryi. Jej postać z wyciągniętą prawą ręką jest zwrócona w kierunku idącej kobiety. Linia horyzontu, na wysokości połowy płótna, dzieli obraz na dwie strefy: nieba i ziemi. Kolorystyka obrazu - złociste ugry i brązy, wskazuje na wczesną jesień. Widoczne są krótkie pociągnięcia pędzla. U dołu po lewej stronie znajduje się sygnatura autora: „krzyżyk, Adam Chmielowski/Kraków 88 r.".

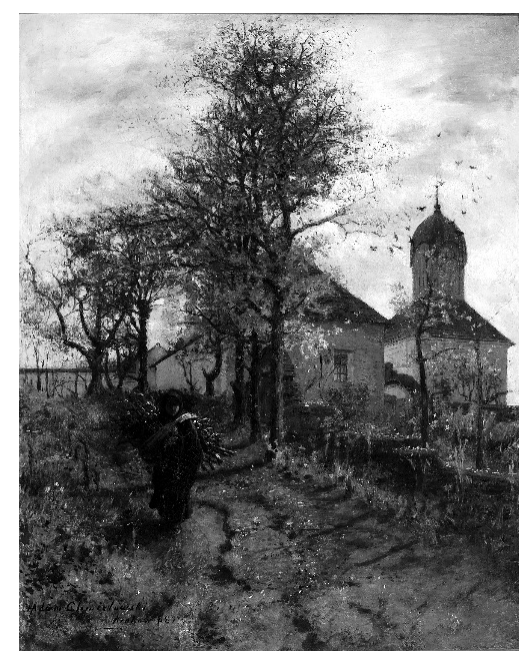

Źródło: https://cyfrowe.mnw.art.pl/p1/katalog/510715 (dostęp: 31.12.2020).

${ }^{6}$ Por. F. Woltyński, Adam Chmielowski (Brat Albert) jako malarz, Kraków 1938, s. 14. Chmielowski przyjaźnił się z Leonem Wyczółkowskim, o czym świadczy fakt, że w latach 1879-1880 przebywał u niego we Lwowie, stąd cytowana relacja jest niezwykle cenna. 
W 1888 r. Chmielowski wystawił Opuszczona plebanię w Towarzystwie Przyjaciół Sztuk Pięknych w Krakowie. Alicja Okońska podaje, że obraz został zakupiony przez Towarzystwo wraz z innym jego płótnem - Wieczór jesienny. Oba dzieła wylosowali Konstanty Liderski i Jakub Nowak?

\section{Interpretacja}

Woltyński stwierdza, że Chmielowski z pór roku najbardziej lubił jesień ${ }^{8}$. Obraz Opuszczona plebania jest tego dowodem. Ciepłe żółcienie, jasne brązy muśnięte złotem oddają doskonale koloryt wczesnej jesieni. Ale to jedyny radosny akcent przedstawienia, ponieważ cały obraz emanuje smutkiem i niepokojem. Może stanowić malarskie studium samotności i opuszczenia. Taką ekspresję artysta osiągnął za pomocą treści (samotna kobieta, nieuczęszczana droga, opuszczona plebania, stado czarnych ptaków nad wieżą kościoła) oraz kontrastu kolorystycznego i światłocieniowego.

Samotność kobiety znamionuje niesiona przez nią wiązka chrustu na opał, która przytłacza ją swoim ciężarem. Prawdopodobnie kobieta nie ma nikogo bliskiego, kto mógłby jej pomóc, wyręczyć w pracy ponad jej siłę. Pochylona sylwetka i biedny ubiór sprawiają, że postrzega się ją jako osobę starą. Dopiero uważniejsze przyjrzenie się twarzy rozjaśnionej światłem słońca z prawej strony odsłania jej młodość. Powolny i ciężki krok, smutek na twarzy, zamyślenie i nieobecność wyrażają udręczenie, ale i pogodzenie z losem. Wiązka chrustu, którą dźwiga, zlewa się z kobiecą postacią, jakby niesiony ciężar był nieodłącznym elementem jej egzystencji.

Kobieta idzie drogą porosłą trawą, a więc rzadko uczęszczaną, zapomnianą. Świadczą o tym kępy zielonej trawy, gdzieniegdzie poprzecinane bruzdami ziemi. Obok drogi znajduje się opustoszała plebania z zaniedbanym ogrodem, otoczonym zmurszałym murem. W budynku plebanii najbardziej wymowne są okna. Bez firanek i kwiatów, odsłaniają fragment pustego wnętrza. Niezamieszkana plebania to nieobecność kapłana, a więc i brak opieki duchowej, kultu Eucharystii, ostatecznie brak namacalnej obecności Boga.

Na obrazie występuje duży kontrast pomiędzy jasnym niebem a cieniem drogi. Sprawia on, że niebo wydaje się bardzo oddalone od ziemi. Pokrywają go białe, ciężkie chmury z małymi prześwitami błękitu. Jest groźne i niedostępne. Dodatkowo czarne ptaki nad wieżą kościoła wprowadzają element niepokoju. Odnosi się wrażenie, jak gdyby przed chwilą poderwały się do lotu spłoszone jakimś ruchem lub hałasem. Występuje wyraźna dysharmonia pomiędzy ciszą strefy pejzażu a groźnym niebem.

Na ile nastrój omawianego obrazu oddaje obraz duszy malarza w 1888 r.? BiografowieChmielowskiego wskazująraczej na wydarzenia potwierdzające w tym czasie jego pokój duszy, wyrażający się w zewnętrznej aktywności. W 1888 r.

${ }^{7}$ A. Okońska, Adam Chmielowski. Brat Albert, Warszawa 1967, s. 246. Członkowie Towarzystwa Przyjaciół Sztuk Pięknych kupowali akcje, które upoważniały ich do udziału w corocznym losowaniu dzieł sztuki zakupionych przez Zarząd Towarzystwa.

${ }^{8}$ Por. Woltyński, Adam Chmielowski, s. 38. 
złożył on śluby tercjarskie na ręce kard. Albina Dunajewskiego. W tym samym roku zapoczątkował powstanie Zgromadzenia Braci Trzeciego Zakonu św. Franciszka Posługujących Ubogim. Został członkiem Konferencji św. Wincentego à Paulo i rozpoczął oficjalną pieczę nad bezdomnymi w Krakowie. W 1888 r. ukazał się także drukiem Przewodnik dla Zakonu Świętego Franciszka jego autorstwa ${ }^{9}$. Nie porzucił także działalności artystycznej. Wstąpił do Towarzystwa Malarzy i Rzeźbiarzy, a w Towarzystwie Przyjaciół Sztuk Pięknych wystawił obrazy: Wieczór jesienny, Poranek zimowy, Modlitwa poranna i Opuszczona plebanię ${ }^{10}$. Był więc to rok pełen aktywności ukierunkowanej, powiązanej z wyborem nowej drogi życiowej.

Jeżeli obraz jest lustrem duszy artysty, to na pewno odzwierciedla inny czas: doświadczenie samotności, udręczenie, poczucie opuszczenia przez Boga. Stąd należy rozważyć, czy nie został namalowany kilka lat wcześniej, a ukończony dopiero w Krakowie w 1888 r.

O tym, że Chmielowski nie zawsze kończył rozpoczęte obrazy wspominają biografowie. Według ks. Mariusza Ślipki jedną z przyczyn tego mogło być dążenie do stworzenia dzieła doskonałego. Jeżeli obraz na taki się nie zapowiadał, nie spełniał jego oczekiwań, to odstawiał go na bok lub niszczył. „Chmielowski - pisze Ślipko - zawsze pełen ideałów, chciał tworzyć majstersztyki. Niszczył wiele własnych obrazów lub ich nie kończył" ${ }^{11}$. Jednak wydaje się, że nie chodzi tu tylko o perfekcję, ale raczej o niemożność wyrażenia siebie, przelania swej duszy na płótno.

Przykładem takiego wewnętrznego zmagania się Chmielowskiego z tematem jest szeroko opisany w literaturze obraz Ecce Homo (1881, kaplica Sióstr Albertynek w Krakowie), który uważa się za przełomowy w jego rozwoju duchowym, chociaż ma formę szkicu. Być może Chmielowski z czasem zaakceptował zasadę, że obraz, który zawiera przesłanie, nie musi być dopracowany w szczegółach, gdyż już przemawia samą treścią. To zapewne wpłynęło też na jego sposób tworzenia. Najpierw chciał przelać na płótno to, co było dla niego ważne, a potem ewentualnie skupiał się na detalach.

Z kolei Teresa Jankowska pisząc o rozpoczęciu działalności zakonnej Chmielowskiego, podkreśla, że: „Brat Albert definitywnie kończy ze sztuką. Jest to dla niego bolesny moment. Wykańcza tylko rozpoczęte obrazy, żeby je sprzedać". Następnie wymienia tytuły obrazów, które w 1888 r. Chmielowski wystawił w Towarzystwie Przyjaciół Sztuk Pięknych. Wśród nich była Opuszczona plebania ${ }^{12}$.

Nie musiało to wyglądać tak dramatycznie, jak przedstawiła to cytowana autorka. Jest oczywiste, że wystawiając obrazy publicznie, należało je dopracować od strony warsztatowej. Natomiast cenna jest informacja, że Chmielowski „wykańcza tylko rozpoczęte obrazy”, co potwierdza jego dwuetapowy sposób pracy.

\footnotetext{
${ }^{9}$ Por. T. Jankowska, Człowiek, który umiał przekreślić siebie. Brat Albert Chmielowski, Warszawa 2011, s. 77.

${ }^{10}$ Tamże, s. 85.

${ }^{11}$ M. Ślipko, Doświadczenie nocy ciemnych $w$ życiu św. Brata Alberta jako droga do postawy mitosierdzia, Wrocław 2018, s. 37.

${ }^{12}$ Por. Jankowska, Człowiek, który umiat przekreślić siebie, s. 85.
} 
Nic więc nie stoi na przeszkodzie, aby przyjąć założenie, że Opuszczona plebanię Chmielowski namalował o kilka lat wcześniej niż wskazuje na to data na sygnaturze, a w 1888 r. obraz dokończył13.

Już przy pierwszym odbiorze dzieła można zauważyć, że jego impresjonistyczna kolorystyka nie współgra z treścią. Prawdopodobnie Chmielowski chcąc wystawić obraz, postanowił rozjaśnić jego pierwotną tonację. Dodał jasne brązy i złote bliki, trawę ożywił czerwonymi plamkami kwiatów.

W 1880 r. Chmielowski wstąpił do jezuitów w Starej Wsi. Po kilku miesiącach odszedł z zakonu ze względu na zły stan zdrowia psychicznego, wymagający leczenia szpitalnego. Po kilku miesiącach pobytu w szpitalu w Kulparkowie został stamtąd zabrany przez brata Stanisława do majątku w Kudryńcach nad Zbruczem, na Podolu. Przebywał tam od 1882 do 1884 r. Momentem przełomowym w powrocie do zdrowia stało się spotkanie z ks. Leopoldem Pogorzelskim z Szarogrodu. Kapłan ten, oprócz pomocy duchowej, zainteresował Chmielowskiego postacią św. Franciszka i działalnością tercjarską, którą ten za kilka lat uzna za swoje powołanie życiowe ${ }^{14}$.

To, co zostało u Chmielowskiego zdiagnozowane jako zaburzenia psychiczne, było stanem duchowym, przeżywanym przez niektórych świętych jako noc mistyczna, niekiedy objawiająca się na zewnątrz jako choroba ${ }^{15}$. Po latach sam Chmielowski wyznał: „Byłem przytomny, nie postradałem zmysłów, ale przechodziłem okropne lęki i katusze, i skrupuły najstraszliwsze"16. Dalej trzeba oddać głos św. Janowi od Krzyża:

Zmysły i duch czują się wtedy jak gdyby przygniecione jakimś ogromnym ciemnym ciężarem. (...) Ten przytłaczający ciężar jest tak wielki, że dusza czuje się z daleka od jakiejkolwiek łaski, wydaje się jej, i tak jest rzeczywiście, że nie znajdzie już oparcia nawet w tym, co ją przedtem podtrzymywało. Sądzi, że wszystko już stracone i nie ma nikogo, kto by się nad nią użalił. (...) Największą boleścią dla duszy w tym stanie jest to, iż wydaje się jej wyraźnie, że Bóg ją opuścił i odrzuciwszy, wtrącił w ciemnośćc ${ }^{17}$.

Noc mistyczna jest procesem, a czas jej trwania i natężenie cierpienia zależy od łaski Bożej i indywidualnych predyspozycji człowieka. Stanowi doświadczenie duchowe, które trudno wyrazić. Chmielowski jako malarz miał narzędzie obraz.

Dlaczego wzrok zatrzymuje się na tym fragmencie pejzażu i chce go utrwalić na płótnie? Bo odnajduje w nim obraz własnej duszy. Z kolei przez obraz nawią-

${ }^{13}$ Podobnie było z innymi obrazami Chmielowskiego: Ulica $w$ podolskim miasteczku, Czarnokozińce. Jak same tytuły wskazują, zostały namalowane podczas pobytu artysty na Podolu w latach 1882-1884, a wystawione w Krakowie, dopiero w 1886 r. Tamże, s. 70.

${ }^{14}$ Por. S. Fita, T. Glemma, M. Piwocka, Chmielowski Adam, Encyklopedia katolicka, t. 3, red.

R. Łukaszczyk, L. Bieńkowski, F. Gryglewicz Lublin 1985, kol. 197.

${ }^{15}$ Hagiografia zna takie przypadki (św. Augustyn, św. Teresa z Avili).

${ }^{16}$ K. Michalski, Brat Albert, Poznań 1978, s. 49.

${ }^{17}$ Jan od Krzyża, Dzieła, Kraków 1986, s. 453-454. 
zuje się duchowa łączność pomiędzy artystą, a widzem, co Chmielowski ujął jako „mowa ducha"18.

Po powrocie do zdrowia Chmielowski zaczął malować. Na płótnie utrwalał okoliczne krajobrazy: Jar podolski jesienia (1882-1884), Zawale, 1883 (Muzeum Narodowe w Krakowie), Czarnokozińce nad Zbruczem (1886), odnawiał obrazy religijne w kościołach i kaplicach. Według Adolfa Nowaczyńskiego w tym okresie wykazywał dużą aktywność artystyczną:

Dużo obrazów Chmielowskiego - pisze Nowaczyński - ukrywa się jeszcze po kościołach na rosyjskim Podolu w szerokim promieniu od wsi Kudryńce, majętność Jego brata (1870-1880). Tego, co zebrano i sprezentowano już w Krakowie - płócien: 40 , a więc multum ${ }^{19}$.

Powrót do zdrowia Chmielowskiego, przejawiający się w aktywności malarskiej, może świadczyć o powolnym dostrzeganiu sensu tego, co w duszy przeżywał, jakby ujrzenie światełka w ciemnym tunelu. Jankowska pisze, że wracając do Krakowa „niektóre obrazy zabrał z sobą...”20. Wśród nich mogła być Opuszczona plebania.

Dwa obrazy Chmielowskiego znajdujące się w Muzeum Narodowym w Warszawie są tak różne, że trudno przyjąć, iż są dziełem tego samego artysty. Pierwszy, mało widoczny, gdyż farby pociemniały, przedstawia pary kochanków w ogrodzie romantycznym, gdzie wzrok przykuwa płonący, jakby na ołtarzu, ogień - symbol miłości. Odsłania on tęsknotę i młodzieńcze marzenia Chmielowskiego o wielkiej miłości. Drugi obraz to Opuszczona plebania, zapis jego cierpienia duchowego bramy do wielkiej Miłości.

\section{REFERENCES / BIBLIOGRAFIA}

Chmielowski Adam, $O$ istocie sztuki, „Ateneum: pismo naukowe i literackie”, 2 (1876) z. 5, s. 428-431.

Fita Stanisław, Glemma Tadeusz, Piwocka Maria, Chmielowski Adam, Encyklopedia Katolicka, t. 3, red. R. Łukaszyk, L. Bieńkowski, F. Gryglewicz, Lublin 1985, kol. 197199.

Jankowska Teresa, Czlowiek, który umiat przekreślić siebie. Brat Albert Chmielowski, Warszawa 2011.

Michalski Konstanty, Brat Albert, Poznań 1978.

Nowaczyński Adolf, Najpiękniejszy człowiek mego pokolenia. Brat Albert, Lublin 1999.

Okońska Alicja, Adam Chmielowski. Brat Albert, Warszawa 1967.

Ślipko Mariusz, Doświadczenie nocy ciemnych w życiu św. Brata Alberta jako droga do postawy mitosierdzia, Wrocław 2018.

Woltyński Franciszek, Adam Chmielowski (Brat Albert) jako malarz, Kraków 1938.

\footnotetext{
${ }^{18}$ Por. Chmielowski, O istocie sztuki, s. 431.

${ }^{19}$ A. Nowaczyński, Najpiękniejszy człowiek mego pokolenia. Brat Albert, Lublin 1999, s. 85.

${ }^{20}$ Jankowska, Człowiek, który umiat przekreślić siebie, s. 64.
} 


\title{
THE PAINTING IS A PROJECTION OF THE ARTIST'S SOUL BASED ON THE WORK OF ADAM CHMIELOWSKI „ABANDONED PRESBYTERY” (,OPUSZCZONA PLEBANIA”)
}

\begin{abstract}
Adam Chmielowski, later St. Brother Albert, studied painting in Munich, in the years 1870-1874. There, he met a group of Polish artists who, like him, left Poland after the January Uprising and the closing of the Academy of Fine Arts in Warsaw. Artistically, they formed a fairly homogeneous group. They cultivated a romantic vision of art. They preferred landscape to traditional historical painting. Their works referred to Poland (the January Uprising, Polish landscapes). The paintings had a specific mood, an air of mystery and contemplative silence. Currently, they are referred to as the „Munich School”. Adam Chmielowski belonged to this group as well. His views on art were probably shaped already in Munich, and he remained faithful to them until the end of his artistic career. For him, a painting should reflect the soul of an artist. This way, through their art, the artist can make a connection with a viewer and vice versa.

The subject of the article is an attempt to get to know the soul of Adam Chmielowski on the basis of his painting „Abandoned Presbytery”. The painting shows the state of spiritual suffering, the experience of abandonment by God and people. The juxtaposition of events in Chmielowski's life with the expressiveness of the painting suggests that it was painted several years earlier (in the years 1882-1884) than what the date on the signature indicates.
\end{abstract}

Keywords: Adam Chmielowski; Brother Albert; „Abandoned Presbytery”; painting; „Munich School” 